\title{
Entering the Void: Exploring the Relationship Between the Experience of Colonisation and the Experience of Self for Indigenous Peoples of Aotearoa, and the Implications for Psychotherapeutic Clinical Practice
}

\author{
Wiremu Woodard and John O'Connor \\ Psychotherapy Practitioner, Psychotherapist, Auckland
}

\section{Whakarāpopotonga}

E tūhurahia ana e tēnei pepa te hononga i waenga i ngā wheako o te pēhitanga me ngā wheako tuakiri mō ngā tāngata o Aotearoa. Ko tā te kaituhi matua tuhinga rangahau o te Paetuarua Whakaora Hinengaro rua mano mā waru te tūāpapa o tēnei pepa. I whāia e ia tētahi momo tikanga arotakenga pukapuka noho ai i raro i te anga rangahau kaupapa Māori ki te tūhura i te wheako tuakiri mo te iwi taketake o Aotearoa me te hononga atu ki te wheako pēhitanga. E whakamātauhia ana e te pepa te hātepenga o te whakaiwitanga: te waihanga me te tukunga whakapūrotohanga (interiorisation) iho ki te iwi taketake ko "Atu". E whakapae ana te pepa ko te hua o tēnei hātepe he whakahārangi tinana iwi taketake he hanga wheako tōtara wāhirua wheako mōriroriro tuakiri mo ngā iwi taketake. I Aotearoa nei, e whakahauhia ana ko te whakaharahara o te whakamā me te mate Mãori te wheako Māori o tēnei tuakiri mōriroriro tōtara wāhirua hoki. E whakape ana tēnei pepa tērā pea e ahu katoa ake ngā whakararunga hinengaro ki te iwi taketake o Aotearoa mai i ēnei wheako waiaro. E whakaarohia ake ana he rara mō te whakaora hinengaro. E werohia ana te whakaora hinengaro me ngā kaiwhakaora hinengaro kia hoki anō ki te whakamātautau i ngā ariā tōrunga pekepoho tuakiri me te haerenga haere tonu o te hātepe pēhitanga kia mātau ake ai kia angitū ai te mahi tahi i te taha o ngā hāpori Māori i Aotearoa.

\section{Abstract}

This paper explores the relationship between the experience of colonisation and the

\footnotetext{
Woodard, W., \& O'Connor, J. (2019). Entering the void: Exploring the relationship between the experience of colonisation and the experience of self for Indigenous peoples of Aotearoa, and the implications for psychotherapeutic clinical practice. Ata: Journal of Psychotherapy Aotearoa New Zealand, 23(1), 89-112. https://doi.org/10.9791/ajpanz.2019.09
} 
experience of self for Indigenous peoples of Aotearoa. As we celebrate the formation of Waka Oranga in $\mathbf{2 0 0 7}$, and its work in the years since, the publication of this paper is particularly fitting, drawing as it does on research originally undertaken at the time of the roopu's formation. It is based on the lead author's 2008 Master of Psychotherapy dissertation research in which he undertook a modified systematic literature review located within a kaupapa Māori research framework, in order to explore the experience of self for Indigenous peoples of Aotearoa and its relationship to colonisation. The paper examines the process of racialisation: The construction and resulting interiorisation of Indigenous peoples as 'Other'. The paper contends that this process has the effect of disrupting indigenous ontologies creating a divided and alienated experience of self for Indigenous peoples. Within Aotearoa, the phenomenon of whakamā and mate Māori are hypothesised as the indigenous experience of this alienated and divided self. The paper suggests that arguably all psychological distress for Indigenous peoples of Aotearoa arise to some degree from these experiences. Implications for psychotherapy are considered. Psychotherapy and psychotherapists are challenged to re-evaluate both the underlying positivist conceptualisations of self, and ongoing processes of colonisation, in order that they may be more fully equipped to effectively work alongside indigenous communities in Aotearoa.

Key words: Indigenous, Māori, self, psychotherapy, colonisation, void

\section{Introduction}

Ko Ōhinemataroa te awa

Ko Te Rewarewa te marae

Ko Te Purewa te tangata

Ko Te Māhurehure te hapū

Ko Tūhoe te iwi

\section{Tihei Mauri Ora!}

I have grown up within a generation of urban Māori whose parents left their rural upbringings in search of new futures in shining metropolises. Being the child of a bicultural marriage, I embody something of the cultural struggle between Māori and Pākehā. My life has been defined by a constant search for belonging. Being a brown Pākehā or a pale Māori, I have always felt myself experienced as 'Other'. The question of who I am and where I belong has coloured the lens through which I perceive the world.

In my work as a psychotherapist, I have often witnessed what Durie (2001) refers to in Māori clients as a sense of "identity diffusion and anomie" (p. 131). As in my story, these existential phenomena usually manifest around questions of identity. Fanon (1982) identifies these experiences for Indigenous peoples as "the zone of non being" (p. 8) and Smith, L., (1999) as a "state of nothingness and hopelessness" (p. 88).

This paper is based on my dissertation research undertaken for my Master of Psychotherapy, in which I conducted a modified systematic literature review located within 
a kaupapa Māori research framework, in order to explore the experience of self for Indigenous peoples of Aotearoa and its relationship to colonisation. The genesis for this research arose out of my observations and experiences of contemporary psychological and social issues effecting Indigenous peoples. The paper explores the subjective experience of self for Indigenous peoples of Aotearoa. It considers the experience of a fragmented sense of self and the struggle of Indigenous peoples to manage the relentless effects of a violent colonisation process, and the search for a future in a modern and post-modern world.

\section{Overview of Methodology Underpinning the Research}

As a Mãori researcher, one walks alongside the community being researched, with the responsibility to ensure that Māori research by, with and for Māori is about regaining knowledge and our resources. We are thus enacting our tino rangatiratanga over research that investigates Māori issues. (Cram cited in International Research Institute for Māori and Indigenous Education, 2006, p.9)

Numerous authors (Clothier, 1993; Cram, 2001; Hoskins, 2001; Pihama, 1993; Pohatu, 2004; Smith, G., 1997; Smith, L., 1999; Stewart-Harawira, 2005; Walker, S., 1996) identify the problematic nature of research for Indigenous peoples, with research simultaneously used as a mechanism for colonial oppression and a contested site for emancipation. This research utilised a kaupapa Māori research theory (KMT) to mediate this tension. As Smith notes,

It is surely difficult to discuss research methodology and Indigenous Peoples together, in the same breath, without having an analysis of imperialism, without understanding the complex ways in which the pursuit of knowledge is deeply embedded in the multiple layers of imperial and colonial practices. (Smith, L., 1999, p. 2)

Therefore, in undertaking this systematic literature review, exploring literature reflecting upon the psychological experience and consequences of colonisation for the experience of self for indigenous Mãori, the principles of KMT guided and informed the literature review.

\section{Kaupapa Māori research theory (KMT)}

Many indigenous authors (Bishop, 2005; Cram, 2001; Clothier, 1993; Jackson, 1996; Nepe, 1991; Pihama, 1993; Pohatu, 2004; Smith, L., 1999, 2005; Stewart-Harawira, 2005; Walker, S., 1996) argue that research and research methodology has been intractably interwoven within the colonising ideology. Research has been utilised as a device legitimatising colonial oppression of Indigenous peoples. Smith, L., (1999) states: "In a very real sense research has been the encounter between the West and the Other" (p. 8).Cram (2001) describes researchers as the mediators of both the space and power differentials that potentially exist between themselves and those being researched.

KMT is an attempt by indigenous researchers to develop their own methodology in order to take ownership of research. KMT draws from an indigenous knowledge base to construct meaning (Pihama, 1993) and includes rectifying the damage of oppressive 
practices and promoting a social change agenda. Several key principles have been identified to guide indigenous research (Cram, 2001; Hoskins, 2001; Pihama, 1993; Pohatu, 2004; Smith, G.,1997; Smith, L.,1999). These principles are outlined in appendix 1. These principles meant that literature generated by Māori authors, and authors providing a critical analysis of colonisation and its effects, were prioritised.

\section{Findings of the Literature Review:}

\section{Colonisation and the Alienation of an Indigenous Self: Loss of Land}

According to Durie (2005) the experience of colonisation for Indigenous peoples across the world has been disastrous and can be defined by a common pattern of loss: "the loss of culture, loss of voice, loss of population, loss of dignity, loss of health and loss of traditional methodologies" (p. 136). Literature reviewed suggests that the damage experienced by Indigenous peoples reflects the disruptive patterning inherent in the colonisation process. Colonisation is motivated by an imperialist desire to acquire land and greater resources (Durie, 2005; Fanon, 1983; Renwick, 1991; Walker, R., 1990; Williams, 2001). The principal consequence of this process has been the alienation of Indigenous peoples from land.

In Aotearoa, in 1862 and 1865 the new settler government (established in 1854) imposed the Native Land Acts (Durie, 2005). These new laws replaced indigenous systems of collective land tenure with individualisation of title. Durie (2005) observes that this legislation impacted directly on Indigenous peoples at two interconnecting levels: Firstly, the acquisition of land by settlers was vastly simplified, resulting in swifter erosion of indigenous land title. Secondly indigenous systems of land tenure were destroyed, further alienating indigenous communities while simultaneously assimilating them into British culture.

In response to the erosion of indigenous rights and loss of natural resources, armed conflict between Crown and Indigenous peoples erupted in the Waikato, Bay of Plenty and Taranaki between 1854 and 1872 . The Indigenous peoples were labelled as insurgents and tribal lands forcibly confiscated by the Crown. In 1840, Māori owned 29,8880,00o hectares of land in Aotearoa. By 1900, land alienation had eroded tribal estates to 3,200,000 hectares and by 2001 Māori land holdings had fallen to 1,515,071 hectares (Durie, 2005, p. 60).

As land tenure, fishing rights, hunting and gathering rights and other natural resources were progressively legislated and lost, Mãori became increasingly alienated from the land and its ecology. The reorganisation of land usage heralded the disappearance of an indigenous ecologically based society underneath the weight of the British colonising initiative (Durie, 2005, pp.13-15). According to Price cited in Park (2006, p. 222) the indigenous predicament is one of lost access and rights to resources; An ecological system on which culture and history depend.

Significantly the apparent demise of the Mãori population in the 1890 s was mirrored by the systematic destruction of the indigenous landscape and ecology. Parks (2006) notes in that decade alone "British settlers torched forests equivalent to 14 percent of New Zealand's land area, making it one of the most active frontiers in the world in terms of the ecological change wrought” (p. 222).

Park (2006) traces the impact of the superimposition of an alien ecology on Indigenous 
peoples of Aotearoa. He states that the venture to create the "Britain of the South had pitched the Māori landscape from a productive ecology to one of loss” (p. 88). Park links the loss of physical resources with the felt experience of psychological anguish and pain for Indigenous peoples:

When a long-term association with the land - long enough to define yourself as being of it, long enough to know it as what fed your mother and hers - is summarily injured or reorganised, as most of the Māori landscape was between 1840 and 1890 , it causes psychological pain. (p. 88)

Furthermore, documentation as far back as the early nineteenth century records this link between the alienation of Indigenous peoples from natural resources and the resultant negative impact on physical and psychological well-being. According to Newman cited in Park (2006):

Mental depression is held by many authorities to have a large effect upon the Māoris, and certainly the loss of their former cropping grounds, of their burial grounds, of the rivers and lakes wherein they formerly fished....and the evident decrease of their race does probably affect a few. (p. 88 )

Durie (2001) uses an analogy of attachment between infants and their mothers to describe the effect of the disruption of the ecological attachment on an indigenous self. Optimal development and the creation of a secure identity for an indigenous self, requires a secure attachment between the person (infant) and the land (mother). When this bond is disrupted and confused, an insecure sense of self follows (p. 79). According to Durie the disorganised identity crisis experienced by contemporary Mãori is a direct result of the disruption of this ecological attachment. The alienation from the land and ecology which colonisation heralded also meant alienation for Indigenous peoples from their indigenous self.

\section{The Ontological Conflict}

A number of authors have suggested (Clammer, Poirier \& Schwimmer, 2004; Fleras, 1999; Havemann, 1999; Hill, 2004; Kawharu, 2003; Linnekin \& Poyer 1990; McCarty, Borgoiakova, Gilmore, Lomawaima, \& Trisanina, 2005; Renwick, 1991; Walker, R., 1987) that when conflicts are closely examined from an anthropological perspective, at their roots lie not only material factors but also ontological conceptions. Cosmo centric as opposed to anthropocentric understandings of peoples place in the universe: Images of nature, ideas of the self, of the body, of gender and of mind-body relationships to name some of the most significant (Clammer et al., 2004, pp.5-6). These in turn are linked in profound ways to ideas of health, healing, religion, identity, food, aesthetics, symbolism, and architecture.

The loss of land is not simply the loss of property, but something closer to the loss of soul, of the material mediator between humans and the universe...in the final analysis, the explication of culture cannot ignore the question of ontologies. (Clammer et al., p.5) 
Arguably, conflict in Aotearoa New Zealand centres upon land and the struggle for control of natural resources. The ontological heart of this conflict is the radically different conceptualisation of self in relation to land and natural resources.

\section{The Ecological Self}

Indigenous peoples (and the concept of indigeneity) are defined through their primary relationship with the land and environments they inhabit and embody. An indigenous self is "fused" with the land (Durie, 2005, p. 137). The land permeates identity, customs, language, lore and rituals (p.137). This understanding of an indigenous self is echoed by other authors (Pere, 1988, 1994; Ra, 2002; Shirres, 1997; Smith, L., 1999; Stewart-Harawira, 2005; Walker, R., 1987). Park, (2006), reflecting on the quality of these relationships for indigenous peoples, observes that for Indigenous peoples:

The wing beats of tūi and kererū overhead spoke of the pulse of the land alive. These people ate from the forest and fished from the sea: forest and sea flowed through them. Living close to other native species, they understood themselves joined in a reciprocal coherence to them. Any sickness or damage that befell the forest befell them. (p. 89)

Park's (2006) poetic descriptor captures an intensely intimate relationship between an indigenous self and the surrounding environment. The premise of an interconnected self, described by Durie $(2003,2005)$ and Park (2006) is a central notion within the formation of the concepts of indigeneity and an indigenous self. The extract also serves as an illustration of the dangers inherent in reconstructing the indigenous self. Park's comparison of Indigenous peoples as "other native species" (p. 223) is a relic of the dehumanising process of colonialism. The tendency to romanticise the relationship between the Earth Mother environment and her children, Indigenous peoples, effectively draws upon unconscious constructions of indigenous communities. Dalal (2002) talks of the romanticism as idealisation, and denigration as a projection, both of which have their roots buried in the ideology of imperialism.

\section{New ways of Being}

Several authors (Belgrave, Kawharu, \& Williams 2005; Durie, 1997, 2001; Kawharu, 2003; Ritchie, 1963; Walker, R., 1987, 1990; Williams, 2001) have noted that initial contact between Indigenous peoples of Aotearoa and early settlers was marked by the ease with which Indigenous peoples embraced new technologies, ideas, symbols and objects into their communities. Durie (2001) describes the paradigm of transcending old into new as characteristic of the first stage of an indigenous response to colonisation. This concept is symbolised in takarangi (Stewart-Harawira, 2005) with the continual reconstitution of an indigenous worldview, in relationship to the surrounding environments.

Stewart-Harawira (2005) in his explication of an indigenous global ontology uses the metaphor of the double spiral or takarangi to capture the ontological and epistemological position of an indigenous worldview. Takarangi literally means chaos and the double spiral represents the concepts of pre-existence and potentiality. The spiral is a symbol representing 
the interconnectedness of all existence. The centre of the spiral is te kore: The void or the realm of potential being, and contains movement towards te ao mārama: The world of light and actualisation, while simultaneously moving back into nothingness.

Stewart-Harawira (2005) observes that an indigenous understanding of interconnectedness is central to indigenous relationships with the environment, both physically and metaphysically. Sampson's (1988) concept of an ensembled indigenous self and Roland's (2006) description of a "we self" (p. 8), also reflects the fundamental element of interconnectedness in the construction of the indigenous psyche. Stewart-Harawira compares indigenous ontologies and epistemologies with critical hermeneutic existential, postmodern and interpretive approaches that understand subject and object as an interrelated whole. Hence the interpretive and explanatory 'circle of understanding' has been expanded into an indigenous 'spiral of understanding'.

Smith, L., (1999) makes a strong case for the prominence of interconnection with the environment. She claims that Indigenous peoples learnt that survival depended on a social structure that simultaneously emphasised cooperation whilst incorporating mobility and adaptability to change:

I believe that our survival as peoples has come from our knowledge or our contexts, our environment, not from some active beneficence of our Earth Mother. We had to know to survive. We had to work out ways of knowing, we had to predict, to learn and reflect, we had to preserve and protect, we had to defend and attack, we had to be mobile, we had to have social systems which enabled us to do these things. We still have to do these things. (p.13)

\section{Granular Society}

In a similar vein, Ritchie (1963) describes Māori society prior to colonisation as 'granular' rather than 'individualistic' or 'cooperative'. Granular according to Ritchie describes society organised around potential rather than formal lines of structure or power. Ritchie's description of a 'granular' Māori society is written in response to the Western projection of a collective or communistic Māori mentality. Although indigenous communities emphasise concerted harmony and mutual cooperation, the projection of a collective mentality is value laden and sits alongside notions of 'primitive' organisations of 'tribal' societies.

Fanon (1983) maintains that colonising communities fear Indigenous peoples grouping together and overthrowing the colonial oppressor. Consequently reification of the idea of the individual occurs. The individual is privileged and promoted as liberal, enlightened and the group or society demoted and denigrated as primitive. In this process Indigenous peoples become naturalised to the echelon of other animals and are described as possessing a hive or swarm mentality (p.33). These suppositions will be revisited more fully in chapters five and six.

\section{Mana ake}

Several authors have considered the contradiction inherent in the idea of an individual indigenous self (Durie, 1995, 2005; Fanon, 1983; Pihama, Cram, \& Walker, S., 2002; Smith, L., 1999; Walker, S., 1996). Developing these ideas, the concept of ecological 'selves' is posited in 
this research as a series of intersecting relationships, a matrix of people and events that are interconnected to the wider environment. This is contrasted with a Western notion of self, the "I-self" (Roland, 2006, p. 2) that is singular, individualised and contained.

This indigenous notion of self is captured by the concept of mana ake (Pere, 1994). The relationship between mana ake and 'selves' can be conceptually traced through a series of interconnected concepts merging the person and the environment. Mana ake is based on the concept of mana whēnua. Mana whēnua is derived from the concept of tangata whēnua, describing the infusion of people with the environment, which is embodied by the concept of whēnua. Whēnua is both land and placenta, both of which nurture, sustain and contain life. This in turn can be associated to the concepts of birth and existence. Mana ake reflects a concept of a fully integrated ecological self, derived from an indigenous paradigm and worldview.

\section{Western Notion of the Individual Self}

By contrast, a Western notion of self is informed by the humanistic model, which splits human from nature and body from mind (Smith, L., 1999). The individual self is contained and internal (Dalal, 2002; Gertz, 1975; Harrington, 1993; Plouffe, 2002; Roland, 2006; Sampson, 1998; Wolstein, 1977) and created and maintained by a regimented sense of the boundaries between individual and society (Ritchie, 1963). Deeply embedded Western assumptions of the individual and individualism are profoundly entrenched in psychological theorising and normative structures (Dalal, 2002; Kleinman, 1998; Krawitz, \& Watson, 1997; Roland, 2006). In making this distinction it is not simply the comparisons between an indigenous experience or notion of self and a Western concept of self that are emphasised; but more significantly it is suggested that it is the imposition of the Western perception of self upon the indigenous understanding of self, that has been key to the devastation of Indigenous peoples of Aotearoa. This process is essentially the colonisation of indigenous 'selves'. The superimposition of a Western notion of self over indigenous 'selves' and consequences for psychotherapeutic practice will be explored in the discussion section below.

\section{Māori Tanga: A Māori Pākehā Dialectic}

The literature reviewed above asserts that the British colonising venture was primarily motivated by the acquisition of land and natural resources. As more land was acquired, Indigenous peoples were driven further from a symbiotic relationship with the land, from an indigenous worldview and ultimately their 'selves'. The consequences of these disruptions have had profound psychological effects (see below).

These colliding ontological realities and the resulting disruption of indigenous 'selves', are analysed by Ritchie (1963) who explores the shift from an indigenous being towards an essential Māori identity. Ritchie traces a parallel internal process mirroring the external patterns of the colonising process. As competition for resources increased, Ritchie argues, so did sensitivity and understanding of how the dynamics of competition were being organised in this new colonial era. The boundaries between people had shifted, creating a new sense of 'us' and 'them'. The 'us and them' had become organised along racial lines. Fanon (1983) stresses that as the divide between human and non-human intensifies, the external split in the colonial situation is mirrored by the internal psyche of Indigenous peoples. 
Ritchie (1963) states that as a response to these dynamics, Indigenous peoples began to operate along increasingly fixed boundaries and social structures. As these external structures solidify so do internal structures. According to Ritchie, colonisation created a rigid sense of self as Māori that is 'Other' to European and British. The dichotomy between Māori and Pākehā was consolidated. Ritchie (1963) asserts that this process was encapsulated by the phenomenon of a proto national Māori culture which further evolved after the land wars between 1854 and 1872 and combined with a series of social pressures; the emergence of the young Māori Party, post war demands and the dynamic urbanisation of Māori. According to Ritchie, these crises cumulated in an indigenous insurrection led by Smith, Best and the Māori Board of Ethnological Research. The intention of the movement was to recover, reconstruct, rectify and revive an image of the Māori past. It heralded the emergence of Māori tanga: Essential 'Māoriness'.

I suggest that the indigenous being or self is co-created through interconnected, symbiotic relationships with the land and other physical resources. An indigenous self is ecological 'selves' and is central to an indigenous worldview. The British colonising project concentrated on the acquisition of land and resources for settlers. As a prerequisite to achieving a colonial state, indigenous claims to land were first extinguished and/or displaced. The consequent alienation and destruction of indigenous 'selves' created a solidified sense of self, which is locked into and constructed by an ongoing relationship with the colonising power. It is suggested that the conflict between settler nations and indigenous 'selves' is a direct reflection of the ontological conflict between British imperialism and an indigenous worldview, and has had devastating consequences for Māori well-being in contemporary Aotearoa New Zealand.

\section{Contemporary Māori Mental Health}

Multiple authors (Baxter, Kingi, Tapsell, Durie, \& McGee, 2006; Bhopal, 2006; Durie, 1998b, 2005; Harris et al, 2006; McCreanor \& Nairn, 2002) note that significant disparities between Māori and non-Māori exist across most social and health related outcomes. Durie (2005) states that Māori patients and particularly Māori women have higher rates of mental illness. Māori are at greater risk for all common mental health disorders, dominating statistics concerning anxiety, depression and substance abuse categories. In addition, Māori tend to exhibit a greater severity of symptoms (p.32).

Durie (2005) observes social disparity and elevated levels of cultural alienation amongst Māori. He asserts that social and material deprivation factors by themselves cannot account for the entirety of disparity between Māori and non-Māori (pp. 42-43). Both Durie (2005) and the MaGPIe research group (2005) note that additional "ethnicity-specific factors" (p. 42 ) appear to be implicated. Durie (2005) ascribes these factors to an indigenous experience of colonisation and the ongoing practice of discriminatory behaviour practiced by the majority group (p.43). Several authors (Beautrais \& Fergusson, 2006; Skegg, Cox, \& Broughton, 1995; Tatz, 2001) note that the qualitative and quantitative experience of indigenous suicide is significantly different for Indigenous than non-Indigenous peoples. Furthermore, Tatz (2001) links indigenous suicide with the experience of colonisation and emphasises the need to understand suicide from without rather than within.

Durie (2001) expresses the colossal effect colonisation has had upon the Indigenous peoples of Aotearoa: "Threats [to well-being] come from many quarters often traceable to 
the process of colonisation and its almost universal accompaniments: depopulation, violence, dislocation, poverty and cultural repression" (p. 35). Durie asserts that it is impossible to understand Māori mental health without understanding the wider historical, cultural and political forces and to appreciate the dimensions of adversity. "The foundations for mental health are to be found as much outside the mind and the body as within" (p. 35).

\section{Divided Self}

"Like the external colonial situation, the internal world of the Negro is inevitably and deeply divided...the self-division is a direct result of colonialist subjugation" (Fanon, 1982, p. 17). The colonising ideology defined 'human' as identical to the coloniser and his world system. Inversely, the colonising ideology worked hard to construct the colonised, the 'Other' as something not human or primitive.

Dalal (2002) summarises Frantz Fanon's (1992) writing in suggesting that "the mythology that colonialism constitutes itself by itself is that it is a civilising project of humanising of the primitive native, and so disguises its true intentions which are exploitative and economic" (p. 94). Fanon writes powerfully about the dehumanisation implicit in the colonial project. "Every colonised people, in other words every people in whose soul an inferiority complex has been created by the death and burial of its local cultural originality - finds itself facetoface with language of the civilising nation" (Fanon, 1982, p. 18). Writers such as Wolfenstein (1993) build on Fanon's work, in offering a reading of colonial discourse in which the construction of the indigenous other as dehumanised is emphasised. Others within the New Zealand context (Durie 2001: Goldie 1989, Kawharu 2003, R. Walker 1987, S. Walker 1996) write, in a manner similar to that suggested by Salmond (2017) of early constructions of indigenous Māori as romanticised and idealised: the noble savage, suggesting this assisted early settler contact, but that as the economic imperative of colonisation became more pressing in the mid and late 19th Century, the constructions of Māori become more violent. Wolfenstein (1993) suggests, "the black race serves as a mirror in which white people see reflected their own unconscious repressed or alienated selves ... the black person is what the white person is not. He is the alienated white self" (p. 354). Writers such as Beets 2003, Hokowhitu, 2004, Park 2006, L Smith 1999, S Walker 1996, write of the construction of Māori as the primitive or savage other.

For example, Walker cites the Wellington Independent (July 21st 1868 cited in Archer), "We must spite and spare not ... they are determined to fight and we, in selfprotection must treat them as a species of savage beasts which must be exterminated to render the colonisation of New Zealand possible.” (p. 6). And Wakefield (cited in Best, 1925, p.120) in describing Māori when telling a story, suggests "nothing can remind one more forcibly of a monkey as one who has seen a Māori relating the news." Darwin (cited in Park 2006 p. 85) comments, "Whenever Darwin remembered New Zealand during the writing of the origin of the species, it was Kororareka's Māori being so "filthily dirty" and his fear of the "cunning and ferocity". On his evolutionary scale of civilisation with terra del fuegians as zero, "I am afraid the New Zealanders would rank but a few degrees higher, while Tahiti ... would occupy a respectable position.” Finally, Arthur Thompson (1859) states, "It was ascertained by weighing the quality of millet seed skulls contained ... that New Zealander's heads are smaller than the heads of Englishmen, consequently the New Zealanders are inferior to the English in mental capacity ... this analysis 
shows the New Zealanders have the minds of children” (p. 81).The above texts illustrate that early colonial constructions of indigenous Māori by European settlers has tended to be ones of either romantic idealisation, or dehumanising denigration.

\section{Internalisation of the Objectified 'Other'}

Dalal (2002) compares Freud (1930) and Winnicott's (1965) developmental concept of the necessity of discovering oneself through and in the eyes of the 'Other', with Fanon's (1982) explication of the indigenous "object" (p.109).

In the colonial situation, the black person has to look in the white mans' eyes to give himself substance, to find himself, but instead of himself he finds the white mans' perception of himself, in effect he is torn asunder and becomes an object to himself. (Dalal, 2002, p. 97)

Fanon (1982) describes the peculiar and devastating phenomenon where in the black man's mind he thinks of himself as white. In this moment the external colonial divide, the split between humanity and beastiality has become interiorised. This occurs when Indigenous peoples are forced to choose and accept the distinctions between the civilised European and Indigenous primitive native.

The external structure is institutionalised in the psyche, rendering the superego white and id black. Now according to Fanon (1983) the Indigenous Antillean has a phobia against blackness. Nonetheless the black person cannot withdraw from their black skin, leading to an experience of self alienation. Essentially the black person is alienated in their black body.

When I had to meet the white mans eyes ....an unfamiliar weight burdened me ...in the white world the man of colour encounters difficulties in the development of his bodily schema. Consciousness of the body is solely a negating activity; it is a third person consciousness. (Fanon, 1983, pp.110-111)

Wolfenstein (1993) critiques Fanon (1983) using a Marxist perspective suggesting the division between the oppressed and oppressors results from an alienating objectification process inherent in capitalist structures. Those subordinate in the hierarchy are forced to identify with the oppressors leading to a divided self. Consequently "the character structure of black children will be partially formed in the oppressors image...white power defines reality and white authority fuses with black parental authority in the formation of conscience" (p. 356). Wolfenstein declares there are now only two possibilities before the marginalised black individual, conformism or rebellion. In either case "the individual is trapped in the vicious circle of self destructive aggression" (p.356).

Elias (1994) in his critique of power relations between groups, states that a coalescence of a 'we' group which is positively cathected, results in the subjugation of a 'them' group which is negatively cathected. The social function of 'we' is to defend the status quo and maintain power differentials. The greater the power differential, the less able the subjugated can defend themselves from internalising these images at fundamental structural and emotional levels. The perceived bad 'them', and therefore self, cannot be escaped and has dire and debilitating 
effects on the psyche. This eventually leads to depression, anger and self-hate.

Elaborating upon Elias (1994), Dalal (2002) states the 'we' idealised images divide and project the bad leaving behind the good. However, if the 'we' image is a denigrated one, then the good will be projected out in order to protect it from the badness within. Both processes effectively reinforce the images of both idealised and denigrated groups simultaneously, effectively maintaining the ideology of the status quo. Dalal (2002) concludes that denigrated images of the 'Other' are deeply embedded in language and societal structures and their images and associations will remain deeply embedded in the psyche of those born into those systems. Effectively the psyche has been racialised.

Erikson (1959) comments: "It is usual in our culture that the unconscious evil identity (that which the ego is most afraid to resemble) is composed of the image of violated (castrated) body, the ethnic out-group and the exploited minority" (p. 30). According to Erikson, children come to interiorise historical or actual people as prototypes of good and evil (p. 24). Erikson suggests that the oppressor in an ethnically prejudiced society has a vested interest in the evil prototypes of the oppressed. Furthermore, the impact upon a person identified as belonging to the oppressed minority is profound.

The individual belonging to an oppressed and exploited minority which is aware of the dominant cultural ideals but prevented from emulating them is apt to fuse the negative images held up to him by the dominant majority with his own identity. (Erikson, 1966, p. 237)

Erikson (1959) states that therapeutic efforts as well as attempts at social reform verify the sad truth that in any system based on suppression, exclusion and exploitation, the suppressed, excluded and exploited unconsciously believe in the evil image which they are made to represent by those who are dominant (p. 31). Consequently, a person will form a negative identity, which is based perversely on all the identifications presented to the individual as most undesirable and dangerous (and real) at critical stages of development ( $p$. 131). The interiorisation of an evil prototype by minority groups is imbibed on unconscious levels and results in a morbid self hate. The evil prototype is interiorised even before the concept of racial difference is obtained.

Several authors (Dalal, 2002; Erikson, 1959; Fanon, 1983; Wolfenstein, 1993) reflect on influences of the socio-political environment on the immediate family structure and refer to the ingestion of social material by the developing infant through the nurturing process. Bollas (1982) describes the mechanism of this process from an object relations perspective:

In my view, each individual transfers elements of that maternal care system that handled them as an object when in infancy and childhood by relocating this parental care system into the person's own way of managing themselves as an object. (p.10)

\section{Internalisation of the Objectified 'Other’ Within the Aotearoa New Zealand Context}

The ideas of the abovementioned international authors (Dalal, 2002; Elias, 1994; Erikson, 1959, 1964, 1966; Fanon, 1983; Wolfenstein, 1993) are powerfully reflected in the indigenous experience of colonisation of the self in Aotearoa. According to Durie (2001, 2005) colossal cultural alienation has been a momentous consequence of the colonisation process: 
Fewer than one third of Māori are proficient in Māori language; Less than one half have access to traditional lands; Less than fifty percent are enrolled on the Mãori electoral roll; One fifth do not know their tribal origins; Approximately one third have regular access to marae, and more than four-fifths live away from tribal areas. (Durie, 2005, p. 44)

The predominant psychological effect recurring alongside the process of cultural alienation has been the destruction of an indigenous identity, creating a confused identity. Durie (2001) comments:

In response to colonisation and attempts at assimilation, Māori identities were often crushed or reconfigured in a fatalistic light. Many Māori rejected their own cultural and social underpinnings of identity and either tried to imitate Pākehā New Zealanders or played out second-class roles as carefree, un-ambitious and inoffensive labourers. (p. 56)

Identity confusion was resolved either through 'opting out' of society or through the creation of a strong negative identity. This reflects the shift from indigenous 'selves' to a colonised Māori identity.

\section{Mana ake}

Durie cited in Pere (1998, p. 59) contrasts a colonised Māori identity to a prior indigenous self. He describes an indigenous self-concept, mana ake, observing that mana ake describes a unique being who is in a constant flux between inner and outer energies and who embodies "a locus of multiple interactive pathways" (p.59).

Vaughan's $(1964,1972)$ psychological studies of ethnic awareness in Māori and Pākehā children, found Māori subjects between four and nine years, failed to show that they are able to identify with individuals of the ethnic in-group (Māori) (p. 5); and up to the age of six years more that half of Māori think that they look like Pākehā. Vaughan concluded: "This phenomenon suggests young Māoris find a Pākehā world attractive to the extent that they see themselves as Pākehās" (p. 56).

Archer (1975) challenges Vaughan's $(1964,1972)$ conclusion that Māori find the "Pākehā world attractive" (p. 52), as understated. Archer (1975) asserts that what Māori think of themselves and their own world, is the more significant issue. He argues Vaughan's (1964, 1972 ) results reflect research findings with regard to American 'blacks' that are described as "conditioned into morbid self-hatred, inferiority feelings and a negative identity" (Archer, 1975, p.34).Vaughan's (1964,1972) supposition is a chilling echo of Fanon's (1982) observation of the Indigenous Antillean coming to think of themselves as white.

\section{Whakamā}

Ritchie (1963) establishes that the Pākehā experience of Māori as 'happy go lucky' is a Māori response to Pākehā expectations and stereotypes. It functions to hide internal conflicts resulting from a divided self. According to Erikson cited in Ritchie (1963, p. 30) the division 
of self, results from the disruption and disturbances in identity formation. Culturally and uniquely expressed it is experienced as whakamā. Whakamā resonates with uncertainty and results in the experience of self-alienation, effectively destroying any capacity to connect with self or others. Ritchie hypothesises the experience of whakamā is pivotal in creating and shaping Māori and Pākehā relations: "In terms of future whakamā is a significant potential difficulty, more so than Pākehā prejudice against Māori” (pp.178-179).

According to Metge (1986) whakamā cannot be understood purely as a psychological problem. Māori see it as an illness with a spiritual dimension, an unease "which affects the whole person body mind and spirit" (p.78). Whakamā are "feelings in the sense of awareness which are characterised by unresponsiveness, that is a withdrawal from communication with others" (p. 25).

Metge observes the experience of whakamā is interwoven with the lack/loss of mana in relation to others. Metge uses the English idiom "to suffer by comparison" (p.32). According to Marsden cited in Metge (1986, p. 77) the loss of mana involves "not only outward alienation from significant others but also inward alienation from oneself”. This links with Wolfenstein's (1993) assertion that self alienation is a direct consequence of objectifying capitalist processes.

According to Barclay cited in Metge (1986, p.32):

In my time, when a Pākehā talks to us...their mind reflects their environment in comparison to ours. We showed we were aware of this by bowing our heads. We sort of drop down in our way of thinking. Everything drops with it if asked a question. We are trying to answer the question and our mind reflects on our environment. If we were on the same level we could look them in the eye... I have been whakamā. In my own mind it's a comparison, comparing the environments, comparing my worth with his worth.

Indeed many of Metge's (1986) vignettes describe the occurrence of what Wolfenstein (1993) refers to as a false conscience: "A divided self who judges the rationality of his actions against the standard of his alienated reality and who therefore acts as to reproduce that reality" (p. 351).

Metge (1986) and Durie (2001) cite Māori author Pere (1994) who describes the concept of tou ake mana "the total individual store" (p. 59). Metge relates tou ake mana to Western psychological terms of self-image and self-concept. Tou ake mana stresses both the uniqueness of the individual and the importance of membership in the group, individual mana being linked reciprocally with that of the group. Metge (1986) observes that both mana and self-image share the characteristic of being sensitive and responsive to the environment. In hostile or infertile conditions mana and self-image will be weak and accompanied by a corresponding experience of powerlessness. Metge states this is both the origin and personification of whakamā. Depending on the severity of whakamā, symptomology can progress into the realm of mate Māori. The person with little or no mana has no protection against the mana of others and more readily falls prey to mate Māori.

Metge (1986) significantly identifies mana as a self-concept, a socially constructed reciprocal relationship. As explored in chapter four, the concept of 'selves', constructed within a social matrix is strongly reiterated by authors reviewed in this section. Of particular interest 
is Foulkes' (1971) central premise: "the group, the community is the ultimate primary unit of consideration, and that so called inner processes in the individuals are internalisations of the forces operating in the group to which he/she belongs" (p. 212) (italics added). Foulkes hypothesises that illness is a malfunction in the communication field. Thus while a person might be ill, "mental sickness has a disturbance of integration within the community at its very roots - a disturbance of communication" (Foulkes \& Anthony, 1957, p. 24). In terms of understanding whakamā and mate Māori, while particular individuals may express ill health and neuroses, they are in fact expressing symptoms of some malfunction in the larger communication field. As Dalal (2002) comments: "The illness is located elsewhere in the system" (p.114).

Metge (1986) outlines the limitations of her research on whakamā, recommending that the experience of whakamā for culturally alienated young (especially urban) Māori be investigated and explored (p. 149). A later research project authored by Van Meijl (2006) investigates this experience of alienated Māori youth within an urban marae setting.

\section{The Dialogical Self}

Van Meijl's (2006) central thesis is that the dissonance between political presentations of the Māori self which are experienced as "theatrical" (p. 4), and the "personal self" (p. 4) representations cause a crisis within Māori, particularly urban youth. Personal self presentations according to Van Meijl are internalised perceptions of Māori culture as 'Other', characterised by a "second rate status in New Zealand society" (p. 4). It is important to note that 'the Other' Van Meijl focuses on his research is not 'the Other' constructed by a colonial majority as investigated in this research. Instead Van Meijl's 'culture of 'Other' focuses upon the 'post' colonial presentation of a crystallised Māori culture as authentic and singular arising from the period of Māori renaissance.

Van Meijl (2006) argues that Māori identity reflects the fragmented nature of a 'post' modern society. He utilises Bakhtin's cited in Van Meijl (2006, p.14) notion of the dialogical self as a framework to locate and explain the phenomena of a post modern multiplicity of 'selves' and the fragmentation of self within marginalised people. The dialogical self is continuously recreating itself and only exists as part of a tensile relationship with all that is 'Other', and most importantly with other 'selves'. Hermens cited in Van Meijl (2006, p. 15) describes the dialogical self as "a society of the mind", where there is virtually no distinction between a self and a society, "both self and society function as a polyphony of constant dissonant voices".

The notion of a dialogical self is remarkably similar to Foulkes' $(1966,1975)$ idea of a social matrix. It also mirrors Stewart-Harawira (2005) and Metge's (1986) descriptions of symbolic interconnectedness and interrelatedness. Undoubtedly the dialogical self resonates with the idea of an indigenous concept of 'selves' located in a reciprocal social and environmental context.

According to Van Meijl (2006), Māori youth in his research were effectively alienated from themselves due to the internalised culture of the 'Other' instigating confusion and dis-unity. The self torn between numbers of conflicting identifications partially disintegrates (dis-unification) with movement and transfer of energy between multiple 'selves' impeded and restricted (p.16). Van Meijl's findings of dis-unification, disintegration and compart- 
mentalisation are remarkably analogous to Metge's (1986) description of whakamā. Dalal's (2002) description of the processes of splitting and categorisation also mirror the internal experience of Van Meijl's (2006) Māori urban youth.

The findings of Van Meijl's (2006) research are both insightful and challenging. His assumption that self alienation occurs because of the internalisation of a classical Māori self is problematic due to his omission of the prior processes of the internalised subjugated 'Other'. Van Meijl's findings are further obscured by his failure to locate himself within the research. Van Meijl as an older, middle class, European male researching young alienated Mãori invariably recreates the very experience he is attempting to observe within his research. Smith, L., (1999) captures this dynamic when she observes that: "Research has not been neutral in its objectification of the 'Other'. Objectification is a process of dehumanisation" (p.39).

The authors reviewed (Dalal, 2002; Elias, 1994; Erikson, 1959; Fanon, 1982; Wolfenstein, 1993) refer to desires constrained by power differentials. Moana desires the clothes in the shop, however she believes she cannot have them. She desperately desires to be white and loved, not brown and hated (Fanon, 1982). Nonetheless, there is no escape from her 'self' or as Fanon cited in Dalal (2002, p. 97) describes she has become "phobic of her skin". As Metge (1986) might observe, Moana is whakamā, she "suffer[s] by comparison" (p. 32.).

\section{Whakamā and the Divided Indigenous Selves}

This research suggests whakamā is more than the divided individual. Whakamā is the massive external cultural and social schism internalised within the psyche of Indigenous peoples. As Fanon $(1982,1983)$ and Wolfenstein (1993) describe the external spilt created by the ideology of colonialism is replicated by the internal psyche of Indigenous peoples. Whakamā is the experience of divided indigenous 'selves'. This statement is premised on Foulkes' $(1966,1975)$ concept of a social unconscious and a social matrix; the idea of interrelated and interconnected relationships pertinent to an indigenous experience of 'selves'. Following Foukles' premise, divided 'selves' or whakamā is an expression of dysfunction occurring in the social environment, expressed by the individual. In this case the dysfunction is caused by the colonisation and subjugation of Indigenous peoples of Aotearoa. Whakamā is the expression of this societal dysfunction.

Applying Dalal (2002) and Elias (1994), whakamā is a uniquely indigenous phenomenon due to its construction from complimentary social roles. It is constituted by rigid power dynamics sourced from and maintained by the imperial colonising ideology: Pākehā at the centre, Māori on the margins.

Metge (1986) and Ritchie (1963) connect the experience of whakamā with many underlying contemporary psychosocial and social issues for Māori in Aotearoa. Fanon (1982) proposes that all neuroses for Indigenous peoples derive from the colonial context and the experience of colonisation. The experience of whakamā is pungently intertwined with the experience of colonisation. A synthesis of these statements suggests that perhaps all contemporary psychological issues facing Māori today are to some degree underpinned by an experience of an objectified and divided self. This hypothesis is further explored in the discussion below. 


\section{Discussion of Findings}

\section{Implications for Psychotherapy in Aotearoa New Zealand: The objectified and divided self}

This research suggests that conceivably all psychological issues for Māori stem to some extent from an objectified and divided self. Fanon (1983) states: "Every neurosis is the product of his cultural situation" (p.152). Dalal (2002) defines this in stating "and by culture he means colonial" (p. 92).

At the heart of this research is the idea that an indigenous experience of self exists within a discursive relationship to colonisation processes. This results in alienation of indigenous 'selves' and the experience of self as an object. "An object has no life force, no humanity, no spirit of its own, so therefore 'it' cannot make an active contribution" (Smith, L., 1999, p. 61).

The theme of an objectified self and the ongoing experience of colonisation is evident in many investigations of mental illness concerning Indigenous peoples of Aotearoa. Tatz (2001) states that the experience of alienation, disempowerment and purposelessness inherent in the motivation for indigenous suicide, stems directly from the experience of colonisation. He correlates these findings with Schulman's cited in Tatz (2001, p.148) notion of "self murder". Durie (2001) observes that the experience of deculturation, loss of language, tradition, cultural institutions and imposed cultural sanctions, underlie excessive substance abuse among indigenous peoples. Durie states that substance abuse is used to relieve a sense of "identity diffusion and anomie" and provides an escape from a sense of "humiliation and socio-cultural inferiority" (p.131).

\section{The Construct of Self - Implications for Psychotherapy}

This research suggests that the concept of self is as much a socio-political construct as it is an internal experience. The construction of self is a socio-political vehicle to validate the colonial experience and colonising processes (Fanon, 1983; Smith, L., 1999; Walker, R., 1987). This has significant implications for psychotherapy and psychotherapeutic practice.

The intention of legislating individualisation of land title in 1862 and 1865 was to simultaneously disrupt indigenous land use and socio-cultural structures (Durie, 2005; Walker, R., 1987). This process was paralleled by an equally insidious process: The individualisation of the self. "The colonialist bourgeoisie had hammered into the natives mind the idea of a society of individuals where each person shuts himself up in his own subjectivity and whose wealth is individual thought" (Fanon, 1983, p. 37).

Colonial ideologies are mirrored and maintained by positivist psychotherapies that split and privilege the internal over the external, the individual over the group and biological over societal (Dalal, 2002; Durie, 2001; Erikson, 1964; Fanon, 1983). These models value depth over surface and the external world is simply seen as the manifest expression of what is real: The latent content of the psyche. The cause of dysfunction is sought within biology and individual development, emphasising the process of projection and neglecting introjection (Durie, 2001; Dalal, 2002; Elias, 1994; Kleinman, 1998; Wolstein, 1977).

In this approach individuals are closed a-historical systems. Thus when positivist psychotherapies scrutinise indigenous psychological issues stripped of history, all that remains to be considered is the dysfunction of the Indigenous. Dalal (2002) and Krawitz, \& 
Watson (1997) contend that therapists must incorporate socio-political history into the analysis, in order to comprehend the complex nature of indigenous symptomology. Further Dalal (2002) states that neglect of the socio-historical, political and the dynamics of power relations will at best only be a partial understanding of what is actually happening and at worst be "dangerously wrong" (p. 217). These ideas are mirrored by Durie (2001) when he asserts:

...emphasis on relationships reflects a Māori belief that personal understanding, knowledge, and awareness derive from outside the individual, not within. Rather than searching for inner psychological comprehension or analysing emotions and behaviour as if they arose de novo, answers are sought in the restitution of positive cultural links and relationships in order to enhance understanding and confidence. (p. 171)

The concept of self must be extended beyond the contemporary modern notion of self: The independent internal phenomenon (Plouffe, 2002; Roland, 2006). For psychotherapy to serve indigenous communities, psychotherapists must understand that client's subjective experience of self has its origins deep within the civilising discourse of imperialism. The Western notion of self was used to subjugate and oppress indigenous populations for exploitation. The unthinking continuation of these models via psychotherapeutic relationships facilitates the ongoing oppression of Indigenous peoples of Aotearoa.

\section{Tino Rangatiratanga and Psychotherapy}

Durie (2001) and Ritchie (1963) both assert that any analysis of the indigenous situation in Aotearoa must include an understanding of the effects of adversity on Indigenous peoples. Through an indigenous experience of adversity the concept of emancipation has developed. The idea of emancipation in Aotearoa is demonstrated by the concept of tino rangatiratanga. Tino rangatiratanga is a powerful indigenous social movement, which underpins multiple contemporary issues for Indigenous peoples (Durie, 1998a). Tino Rangatiratanga concerns indigenous 'selves' forging connections between the self and the environment: The social, political, ecological, cosmological and more. Tino rangatiratanga is posited in this research as an antidote to the experience of whakamā and mate Māori: The divided and alienated experience of self. Tino rangatiratanga has the potential to weave together the split and fragmented 'selves'. Future research in this field would advance the emancipation of Indigenous peoples of Aotearoa. Furthermore this has considerable implications for psychotherapy and psychotherapeutic practice.

Psychotherapy and psychotherapists must carefully consider the positivist Western paradigm that informs their practice, assessment and treatment planning. Tino rangatiratanga demands reconfiguration of the psychotherapist's world-view. Psychotherapists can choose to collude with the colonial ideology, perpetuating the status quo, and maintaining the oppression of Indigenous peoples through racist discourse; or begin forging pathways of understanding the complex dynamics contributing to contemporary constructions of self and society. Tino rangatiratanga requires psychotherapists to firstly 'own' their privileged position. 


\section{Stages of Liberation (Fanon,1983)}

Fanon's stages of liberation describe the initial impact of colonisation. The stages are useful for contextualising concepts of whakamā, mate Māori, and tino rangatiratanga. Fanon's stages of liberation detail his vision of Indigenous peoples transcending colonial oppression and transforming their constructed identity of 'Other' into an identity of indigenous nationhood.

The first stage of liberation is unqualified assimilation: the unquestioned appropriation of colonial ideology. The second stage of liberation is the resurgence of tradition and involves celebrating the very qualities that are denigrated by the settler. Nevertheless this process is inadequate as the indigenous person still perceives him/herself through the eyes of coloniser and so finds him/herself wanting. The third stage of liberation is defined by action with the formation of politicised groups to counter the ideology of the individual, used against indigenous populations as a divisive mechanism.

This research has focused on stage one of Fanon's (1983) model, as it remains a process current in the experience of self of Indigenous peoples of Aotearoa (Smith, L., 1999). In a contemporary context in Aotearoa, the stages are experienced as non-linear with movement within different stages simultaneously taking place (see Smith, L., 1999 commentary).

The movement towards liberation in Aotearoa resurfaced with the arrest, interrogation and violence towards political activists and the Tühoe community under the guise of the Terrorism Suppression Act. In addition, the resolution (and challenge) by Māori psychotherapists to enter the New Zealand Association of Psychotherapists (NZAP) as a group (Waka Oranga) demonstrates a movement towards tino rangatiratanga. Indeed, there are many examples of diverse groups within Aotearoa contributing to the total effort of emancipation. Psychotherapy and psychotherapists have a choice to engage with these revolutionary processes or to retreat and defend the status quo. With regard to clinical practice psychotherapists must, at the least, hold in mind the wider socio-political context within which the Indigenous experience of self emerges; if they are not to perpetuate the very oppression they are purporting to address.

\section{Conclusion}

The implications drawn from this research are presented as a wero for the psychotherapeutic community to engage in a full and meaningful way with Indigenous peoples of Aotearoa. The challenging nature of the discussion is intended to provoke and stimulate dialogue.

In this conversation, psychotherapy must acknowledge the inherent power differential between privileged Western perspectives and oppressed indigenous voices. By reconsidering the therapeutic paradigm to include historical socio-political and environmental elements, psychotherapy opens to the possibility of clearly seeing indigenous psychological issues in their whole context rather than locating the dysfunction within the Indigenous person. This has potentially dramatic implications for contributing to the holistic well-being and health of indigenous communities. 


\section{ENTERING THE VOID}

\section{References}

Archer, D. (1975). Race, identity and the Mãori people. Hamilton: University of Waikato.

Baxter, J., Kingi, T., Tapsell, A., Durie, M., \& McGee, M. (2006, October). Prevalence of mental disorders among Māori in te rau hinengaro: The New Zealand mental health survey. Australian and New Zealand Journal of Psychiatry, 40(10), 914-923.

Beautris, A. L., \& Fergusson, D. M. (2006). Indigenous suicide in New Zealand. Archives of Suicide Research, 10(2), 159-168.

Beets, J. (2003). Girls and boys come out to stay: Ideological formations in New Zealand - set children's fiction 1862 - 1917. New Zealand: Massey University.

Belgrave, M., Kawharu, M., \& Williams, D. (2005). Waitangi revisited: Perspectives on the Treaty of Waitangi. Oxford: Oxford University Press.

Best, E. (1925). Games and pastimes of Māori. Wellington: The Board of Māori Ethnological Research for the Dominion Museum.

Bhopal, R. (2006). Racism, socio-economic deprivation and health in New Zealand. Lancet, 367(9527), 1958-1959.

Bishop, R. (1997). Collaborative research stories: Whakawhanaungatanga. Palmerston North: Dunmore Press.

Bishop, R. (2005). Freeing ourselves from neo-colonial domination in research: A kaupapa Māori approach to creating knowledge. In N. K. Denzin \& Y. S. Lincoln (Eds.), The Sage handbook of qualitative research ( $3^{\text {rd }}$ ed.) (pp.109-138). Thousand, CA: Sage Publications.

Bollas, C. (1982). On relation to the self as an object. The International Journal of Psychoanalysis, 63, 347-359.

Clammer, J., Poirier, S., \& Schwimmer, E. (Eds.). (2004). Figured worlds: Ontological obstacles in intercultural relations. Toronto: University of Toronto Press.

Clothier, H. (1993). Three women speak: A site for constituting identity. Wellington: He Parekereke, Victoria University.

Cram, F. (2001). Rangahau Māori, tona tika, tona pono: Research ethics in Aotearoa. Auckland: Longman.

Dalal, F. (2002). Race, colour and the processes of racialization. New York: Routledge.

Durie, M. (1995). Ngā matatini Māori: Diverse Māori realities. Mental Health Framework Seminar, Tūrangawaewae Marae, Ngāruawahia.

Durie, M. (1997). Māori cultural identity and the New Zealand search for nationhood. Australian and New Zealand Journal of Mental Health Nursing, 6, 51-58.

Durie, M. (1998a). Te mana, te kawanatanga: The politics of Mãori self determination. Auckland: Oxford University Press.

Durie, M. (1998b). Whaiora: Māori health development. Melbourne: Oxford University Press.

Durie, M. (2001). Mauri ora: The dynamics of Māori health. Melbourne: Oxford University Press.

Durie, M. (2003). Ngā kahui pou: Launching Māori futures. Aotearoa: Huia Publishers.

Durie M. (2005). Ngā tai matatū: Tides of Māori endurance. Melbourne: Oxford University Press.

Elias, N. (1994). The civilising process. Oxford: Blackwell.

Erikson, E. (1959). Identity and the life cycle. New York: International Universities Press.

Erikson, E. (1964). Insight and responsibility. New York: W. W. Norton.

Erikson, E. (1966). The concept of identity in race relations. New York: W. W. Norton.

Fanon, F. (1983). The wretched of the earth. New York: Grove Press. 


\section{WIREMU WOODARD AND JOHN O'CONNOR}

Fanon, F. (1982). Black skin, white masks. New York: Grove Press.

Fleras, A. (Ed.). (1999). Politicising indigeneity: Ethno-politics in white settler dominions. Auckland: Oxford University Press.

Foulkes, S. H. (1966). Some basic concepts in group psychotherapy. London: Karnac Books.

Foulkes, S. H. (1971). Access to the unconscious processes in the group-analytic group. London: Karnac Books.

Foulkes, S. H. (1975). Problems of the large group. London: Karnac Books.

Foulkes, S. H., \& Anthony, E. J. (1957). Group psychotherapy: The psychoanalytic approach. London: Karnac Books.

Freud, S. (1930). Civilisation and its discontents (Standard ed., Vol. XXII.). London: Hogarth Press.

Gertz, C. (1975). On the nature of anthropological understanding. American Scientist, 63, 47-53.

Goldie, T. (1989). Fear and temptation: The image of the indigene in Canadian, Australian and New Zealand literatures. Kingston: McGill-Queens.

Harrington, C. (1993). Making culture and making people: Comparative constructivism. Contemporary Psychoanalysis, 29, 251-270.

Harris, R., Tobias, M., Jeffery, M., Waldegrave, K., Karlsen, S., \& Nazroo, J. (2006, June). Effects of self-reported racial discrimination and deprivation on Māori health and inequalities in New Zealand: Cross sectional research. Lancet, 367(9527), 2005-2009.

Havemann, P. (Ed.). (1999). Indigenous peoples' rights in Australia, Canada and New Zealand. Auckland: Oxford University Press.

Hill, R. (2004). State authority, indigenous autonomy: Crown-Māori relations in New Zealand/Aotearoa 1900 - 1950. Wellington: Victoria University Press.

Hokowhitu, B. (2004). Physical beings stereotypes, sports and the physical education of New Zealand Māori. In J. A. Mangan \& A. Ritchie (Eds.), Ethnicity sport: Struggles for status (pp.192218). Oxon: Routledge.

Hoskins, C. (2001). Kia whai kiko te korero: Constituting discourses, exchanges at the edge. Unpublished masters thesis. University of Auckland, Auckland, Aotearoa/NewZealand.

International Research Institute for Māori and Indigenous Education. (2006). A research ethic for researching Māori and iwi provider success. Auckland: University of Auckland.

Jackson, M. (1996). Māori health research and Te Tiriti o Waitangi. A hui to discuss strategic directions for Māori health research, Wellington School of Medicine, Wellington.

Kawharu, S. H. (2003). Conflict and compromise. Reed: New Zealand.

Kleinman, A. (1998). Rethinking psychiatry: From cultural category to personal experience. New York: Free Press.

Krawitz, R., \& Watson, C. (1997). Gender, race and poverty: Bringing the socio-political into psychotherapy. Journal of Environmental Psychology, 31(4), 474-479.

Linnekin, J., \& Poyer, L. (Eds.). (1990). Cultural identity and ethnicity in the Pacific. Hawaii: University of Hawaii Press.

McCarty,T. L., Borgoiakova, T., Gilmore, P., Lomawaima, K., \& Trisanina, R. (Eds.). (2005). Indigenous epistemologies and education: Self determination, anthropology and human rights. Anthropology and Education Quarterly, 36(1), 1-7.

McCreanor, T., \& Nairn, R. (2002). General practitioners explanations of Māori health: Colonial relations in primary healthcare in Aotearoa, New Zealand. Journal of Health Psychology, 7(5), 509-518. 


\section{ENTERING THE VOID}

MaGPIe Research Group, University of Otago at Wellington School of Medicine and Health Science. (2005). Mental disorders among Māori attending their general practitioner. Australian and New Zealand Journal of Psychiatry, 39(5), 401-406.

Metge, J. (1986). In and out of touch: Whakamā in cross cultural context. Wellington: Victoria University Press.

Nepe, T. (1991). E Hao Nei e Tenei Reanga te Toi Huarewa Tupuna: Kaupapa Mãori, An Educational Intervention System. Unpublished masters thesis. University of Auckland, Auckland, Aotearoa/ New Zealand.

Park, G. (2006). Theatre country. Wellington: Victoria University Press.

Pere, R. (1988).Te wheke: Whaia te maramangatanga me te aroha. New Zealand: Ao Ako Global Learning.

Pere, R. (1994). Ako: Concepts and learning in the Māori tradition. Wellington: Kohanga Reo National Trust.

Pihama, L. (1993). Tungia te ururua, kia tupu whakaritorito te tupu o te harakeke: A critical analysis of parents as first teachers. Unpublished masters thesis. University of Auckland, Auckland, Aotearoa/New Zealand.

Pihama, L., Cram, F., \& Walker, S. (2002). Creating methodological space: A literature review of kaupapa Māori research. Canadian Journal of Native Education, 26(1), 30-43.

Plouffe, H. D. (2002). The indigenous healing process and cultural rebirth of first nations. The Sciences and Engineering, 62(10B), 4800.

Pohatu, T. W. (2004). Āta: Growing respectful relationships. Wellington: Massey University.

Ra, M. (2002). Mana a toku ko tane: The right to stand tall. Te Kauwhata: Mitaki Ra Publications.

Renwick, W. (1991). Sovereignty and indigenous right: The Treaty of Waitangi in international contexts. Wellington: Victoria University Press.

Ritchie, J. (1963). The making of a Māori: A case research of a changing community. Wellington: A. H. \&A.W. Reed.

Roland, A. (2006). Across civilisations. The American Psychological Association Journal, 43(4), 454463.

Salmond, A. (1917). Tears of Rangi: Experiments across worlds. Auckland: Auckland University Press.

Sampson, E. E. (1998). The debate on individualism: Indigenous psychologies of the individual and their role in personal and societal functioning. American Psychologist, 43(1), 15-22.

Shirres, M. (1997). Te tangata: The human person. Auckland: Accent Publications.

Skegg, K., Cox, B., \& Broughton, J. (1995). Suicide among New Zealand Māori: Is history repeating itself? Acta Psychiatrica Scandanavica, 92(6), 453-459.

Smith, G. (1997). The development of kaupapa Māori theory and praxis. Unpublished doctoral dissertation. University of Auckland, Auckland.

Smith, L. (1999). Decolonizing methodologies: Research and indigenous peoples. Dunedin: Zed Books.

Smith, L.T. (2005). On tricky ground. In N. K. Denzin (Ed.) \& Y. S. Lincoln (Ed.). The Sage handbook of qualitative research ( $3^{\text {rd }}$ ed.). (pp. 85-107). Los Angeles, CA: Sage Publications.

Stewart-Harawira, M. (2005). The new imperial order: Indigenous response to colonisation. Wellington: Huia Publishers.

Tatz, C. (2001). Aboriginal suicide is different: A portrait of life and self destruction. Canberra: Aboriginal Studies Press.

Thompson, A. (1859). The story of New Zealand: Past and present, savage and civilised. London: John Murray. 
Van Meijl, T. (2006). Multiple identifications and the dialogical self: Urban Māori youngsters and the cultural renaissance. Journal of the Royal Anthropological Institute, 12(4), 917-933.

Vaughan, G. M. (1964). Development of ethnic awareness in Māori and Pākehā school children. Wellington: Victoria University Publication.

Vaughan, G .M (1972). Racial issues in New Zealand. Auckland: Akarana Press.

Walker, R. (1987). Nga tau tohetohe: Years of anger. Auckland: Penguin Books.

Walker, R. (1990). Ka whawhai tonu matou: Struggle without end. Auckland: Penguin Books.

Walker, S. (1996). Kia tau te rangimarie: Kaupapa Māori theory as a resistance against the construction of Māori as the other. London: Zed Books.

Williams, D. (2001). Crown policy affecting Māori knowledge systems and cultural practices. Wellington: Waitangi Tribunal Publication.

Winnicott, D. W. (1965). The family and individual development. London: Tavistock Publications.

Wolfenstein, E. V. (1993). Psychoanalytic marxism: Groundwork. London: Free Association Press.

Wolstein, B. (1977). From mirror to participant observation, to co participant inquiry and experience. Contemporary Psychoanalysis, 13, 381-386.

\section{ApPendix 1 - Principles of KaUpapa Māori Research theory (KMT)}

1. The principle of the Treaty of Waitangi: Te Tiriti o Waitangi (1840) provides a basis through which Māori may critically analyse relationships, challenge the status quo, and affirm Māori rights (Pihama, 2001).

2. The principle of collective philosophy: The kaupapa refers to the collective vision, aspiration and purpose of Mãori communities.

3. The principle of emancipation: Tino rangatiratanga relates to sovereignty, autonomy, control, self determination and independence.

4. The principle of socio-economic mediation: This principle asserts a need for kaupapa Māori research to be of positive benefit to Māori communities.

5. The principle of cultural aspiration: Within a kaupapa Māori paradigm, Māori ways of knowing, doing and understanding the world are considered valid in their own right.

6. The principle of growing respectful relationships: The principle of āta (Pohatu, 2004) relates specifically to building, nurturing and maintaining well-being in relationships with Māori.

7. The principle of extended family structure: The principle of whānau acknowledges the relationship that Māori have with the world around them and to one another. It also identifies the intrinsic connection between the researcher, the researched and the research. 


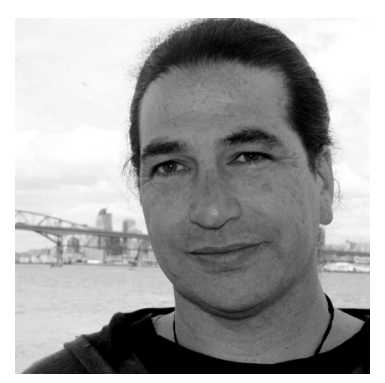

details: wiremu.woodard@aut.ac.nz.

Wiremu Woodard is Tuhoe and an Indigenous therapist, father of four, activist, environ-mentalist, sometimes contemporary dancer and artist. Wiremu is committed to reducing health disparities for Māori and promoting social justice. He currently works in community practice at KERERU and teaches on the Psychotherapy and Counselling programme at Auckland University of Technology. Wiremu is a founding member of Waka Oranga - a group of dynamic Indigenous Māori practitioners committed to emancipatory freedom. Contact

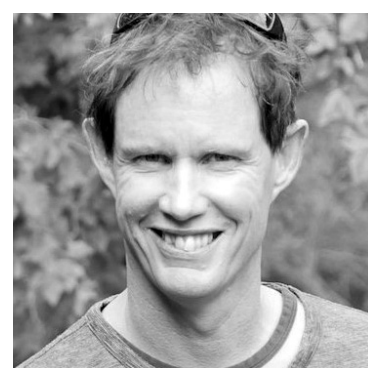

John O'Connor has worked as a counsellor and psychotherapist for over 30 years, and has a wide range of clinical experience, particularly in working with clients with severe trauma histories, in providing group psychotherapy, and in working crossculturally. $\mathrm{He}$ is a former Director of Youthline Counselling Service (Auckland) and the Human Development and Training Institute. He also formerly worked at Segar House (which is part of ADHB Mental Health Services) and was a founding member of the therapeutic team at Segar which developed a residential treatment service (currently operating as a day programme) for clients with personality disorder diagnoses. He has worked as a lecturer at the Auckland University of Technology within the Psychotherapy Discipline since 1999 and was formerly Programme Leader of the Master of Psychotherapy (adult programme) at AUT. He is co-editor of Ata: Journal of Psychotherapy Aotearoa New Zealand. John is an associate member of Waka Oranga. John also conducts a private practice in Mangere Bridge. John is currently a candidate in training as a Jungian Analyst with the Australia New Zealand Society of Jungian Analysts and is undertaking his $\mathrm{PhD}$ exploring the discourses underpinning bicultural clinical encounters in Aotearoa New Zealand. Contact details: johnnygj@xtra.co.nz. Phone 021-899-261. 